\title{
Female terrorist from the Western Balkans as a security threat
}

\author{
Milica Curčić, \\ PhD Candidate at Faculty of Security Studies, \\ E-mail: milicacurcic89@hotmail.com
}

\begin{abstract}
:
Women have been involved in political violence for more than a century, but the academic focus on women terrorists is relatively recent dated. As terrorism is transforming, the role of women is evolving from secular to Islamic religious settings. The Western Balkans is a region that is particularly vulnerable to the appearance of the female terrorist. The number of women from the Western Balkans involved in terrorist activity and leaving from this region to "Islamic State"held territory is growing, which makes phenomenon of female terrorist become more visible in media coverage, scholarly work and counterterrorist official activity.

The paper explores phenomenon of women from the Western Balkans that are involved in terroristic activities in the "Islamic State". The first part of the paper explores motivation of women from the Western Balkans to support and participate in terrorism. The second part of the paper looks at the ways of their recruitment. The third part analyzes the different roles that women plays in terrorist organizations. The last segment of the work focuses on the response of the state and society to this security threat through legislation and the process of de-radicalization.
\end{abstract}

State"

Key words: female terrorist, terrorism, Western Balkans, terrorist organization, "Islamic

\section{Introduction}

Studies have shown that women have had an extensive history of participating in terrorist activities. It has been proven in modern terrorism that female involvement began in the nineteenth century with the Russian People's Will, with the onward appearance of Chechen Black Widows and the Tamil Tiger's Birds of Paradise, and other terrorist organizations, which this paper is dedicated to mention. Women's political violence has most frequently been associated with left-wing movements, and with attempt to resolve fundamental problems in the political and social institutions of society. They have been taking participation within nationalist, often violent conflict. Today, it is especially important to notice evolution of women's political violence from secular to Islamic religious settings. 
In contemporary terrorist groups men are generally in charge, but women play a substantial role in terrorist activity. They participate in combat operations, and also have vital supporting roles. The question that undeniably arises should there be vivid distinction of male and female members of terrorist organizations? There is a increasing number of women that have joined to the terrorist organization, especially the "Islamic state". Also, the role of women in terrorist organizations is altering and growing, which creates the need for a detailed examination of female terrorist phenomena.

Western Balkan, due to its historical and cultural components, and because of its specific geopolitical position, couldn't remain immune on changes that happen in the Middle East. The Wahhabi movement in this region is gaining strength, and since 2011 there is a increasing number of people who went to Syria and Iraq. Those people joined to "Islamic State", and have taken active roles in combat operation (Dragišić, Curčić, 2016:146). As the result of those happenings, the constellation of threats to the security of Western Balkans has been changed.

However, although there is a lot of researches on the security of the Western Balkans in the context of terrorist threats, one topic has been often neglected. That is a question of activity of female terrorist from this region. Women from Western Balkans have being recruited by "Islamic State", and migrating to Syria and Iraq. So it is important to recognize this security challenge and to put a gender-based perspective on counterterrorism policy.

There are differences in reason that attract men and women to join the "Islamic state", and also the roles of women in the Islamic State and the messaging the group uses to lure women to migrate to Syria and Iraq are sufficiently different. In order to understand reasons that pull and push women from this region to become terrorists, we need to explore the specifics of participation women in terrorism. Hence, we should explore their motivations, ways of their recruitment, what are advantages and disadvantages of engaging women in terrorism and which roles they can play in terrorism organization. Then, this knowledge should be applied in research the phenomena of female terrorist from Western Balkan. Also, we should research what states and society should do in order to prevent female involvement in terrorist activity, or which are ways of react on those who had already become members.

\section{Motivation of women to support terrorism}

In analysis of female involvement in terrorism, one of the first question that arise is what motivate women to take participation in terrorist activity? It is important to comprehend that each individual is motivated for a different reason, and that a multitude of reasons may also be combined to influence women to take action in an extreme manner. Some scholars believe that there are differences between men and women in motivation to support terrorism: men are politicized and women are acting out of passion. Society is quick to judge these women as irrational actors. This scenario is not always the case, so it is essential to recognize reasons that motivate women to support terrorism and carry out a terrorist attack.

According to Bloom, women's involvement in terrorism can be motivated by four R's: Revenge, Redemption, Relationship and Respect. Bloom argues that revenge for the death of close 
family member is most often cited as the key factor for women's involvement. Some women are trying to redeem themselves by a willing act of martyrdom. For them, making terrorism is better alternative than facing an honor code that will hold them culpable for past misdeeds. Under the relationship factor, Bloom considers the importance of situation when woman is related to a known insurgent or Jihadi. Finally, although usually in conjunction with other motives, women have sought the respect of their community. By engaging in violence they can demonstrate that they are just as dedicated and committed to the cause as the men of the society (Bloom, 2011:12-13). This attempt to seek a deeper understanding of female motivation phenomenon is worth of attention. But, analyzing Bloom's 4 R categorization, we can notice that it is to general, and as the result some of important factors are neglected. Also, relationship with some other member of terrorist group is way of recruitment, rather than motivation factor.

At the most general level of analysis, the motivation of women to participate in terrorist activities arises from a specific combination of religious, ideological, political and personal reasons. The forthcoming classification provides a broad analytical framework for understanding female motivation to support terrorist activity, because it is applicable on Muslim women, Western women that convert into Islam and join terrorist group, but also on women that participate in secular terrorist group.

\subsection{Commitment to an Ideological Cause}

Political reasons, religious and ethnic beliefs are often a touchstone for the motivation and commitment of females involved in terrorism (Zedails, 2008:52). They have a desire to make significant changes to the current environment and to contribute to a cause that they believe in. In many cases, women are more dedicated to the cause and act more decisively than men because the female gender as a whole has more to gain from significant social changes that may occur from the terrorist movement.

\subsection{Grief or Revenge for Loss}

Grief is a significant motivation that draws wives, mothers, or daughters into extremist organizations. The loss of a dominant male figure in their lives has a tremendous emotional, physical and financial impact. Many female terrorists want to seek revenge on those who have humiliated them in the past; or for family members or on their male counterparts which have oppressed.

\subsection{Financial Problems}

The death of a husband, father or son for females that live inside conflict zones can lead to a loss of economic support for an entire family. Women are often involved in terrorist activities in order to support their families financially and to provide basic subsistence requirements. Many women are sacrificed themselves and became suicide bombers in order to ensure that their family receives a generous amount of money, and on that way enable the rest of family to survive. 


\section{Security}

\subsection{Desire to Improve Social Status}

There are many different reasons that can be classified under the desire to improve social status. When government institutions are able to provide gender equity and opportunities for women in economic, political, and social arenas, it would certainly reduce terrorist movements that appeal to women, and thus, diffusing the infrastructure of such movements (Gonzalez-Perez, 2008:131). Human rights abuse, discrimination and lack of opportunities for women are factors that can generate discontent among women and provide potential mobilization for political violence against the state. Some woman choose to partake in acts of terrorism to bring respect to their status and with involvement in the terrorist group they bring pride to their family and children, and have found eternal paradise for themselves. Also, gaining equality with their male counterparts is a strong motivation to participate in terrorist activities.

\subsection{Personal or Family Shame}

Females will often join terrorist organizations as a way to reinvent themselves or to become pure again after a sexual assault or after been forcibly raped. This shame is not only focused on the individual, but also directed at the entire family. Often women will seek to become suicide bombers to cleanse the indiscretions that they have been accused of, regardless of who is to blame (Sutten, 2009:25). Suicide bombers are considered martyrs and discretions in their past are forgiven and their family honor is restored when they give their life for an ideological cause.

\subsection{Protection of Itself or Family}

In conflict zones, terrorist organizations often provide the basic security mechanism for local towns and villages. Sometimes women turn to support terrorists because they either receive protection from criminals, or other rogue elements, or are afraid of possible retaliation if they do not provide support. The protection provided by terrorist organizations can be more destructive to the local populace since security or military forces see this support as disloyal to the government, and will crack down on supporters (Sutten, 2009:26). This creates a destructive cycle, where women need to choose lesser of two evils.

\subsection{Adventure and romance}

Desires to experience adventure or romance are also factors that attract women to join terrorist organizations, especially women from non-conflict zones, in example, women from Western Europe. Faced with the unexciting and unchallenging environment at home, and seduced with the romance story between the female migrant and the jihadist, they may decide to experience this alluring different way of living. The sense of adventure in leaving home to travel to new places is influential particularly for the younger women. It is worth remembering that a large number of Western women joining ISIS are very young (Saltman and Smith, 2015:16).

It is important to comprehend that motivation factors that influence on women are not only be combined, but also can be changed or transformed over time. Someone who was initially motivated primarily by one set of factors may thereafter gradually change his or her thinking 
based on experience (Persin, 2015:25). All these circumstances indicate the complexity of researching phenomenon of female motivation to participate in terrorist activities. Understanding the motivational factors behind why women get involved in violent acts, may give us an idea of what challenges a society is facing, and in turn the factors that engender conditions in which terrorist organizations are able to recruit and win support.

We presented factors that can motivate women to join terrorist organization in general, and now we should implement that classification to the particular situation in order to understand which factors motivate women from Western Balkans to become terrorist. At first, we need to notice that there isn't active secular terrorist group in this region, and women who participate in terrorist activity are connected to the "Islamic state". Those are Muslim women, or women converted into Islam. They, like a women in any other part of world, can respond to the call made by "Islamic State" leader al-Bagdadi that all Sunni Muslim believers have a "religious duty" to migrate to "Islamic State". Also, women can join to "Islamic State" as a react of well-spread islamophobia, or they can find a sense of purpose in believing that they are part of the founding generation to establish a pure Islamic utopia based on Shari'a law. Hence, as one of motivation factors we can recognize commitment to an ideological cause. If some family members have been killed in Syria or Iraq, it may appear desire for revenge at their mother's, wives, or daughters, so grief or revenge for loss can't be fully excluded as potential motivation factor. High unemployment and the lack of meaningful opportunities for both women and men, particularly in rural areas, are significant contributing factors to the region's radicalization problem. Youth unemployment is even more urgent an issue, as no country in the Western Balkans currently has a youth unemployment rate under 30 percent (Mietz, 2016:7). So, financial problem is one of key motivating factors that drag women into terrorism. If Muslim women from Western Balkans countries believe that they are oppressed in some way or anyhow prevented in practicing their religion, they can choose to partake in acts of terrorism to bring respect to their status. As Western Balkans is non-conflict zone, there isn't necessary for women to join to terrorist organization in order to provide protection of itself or family. Also, there is low level probability that they join to terrorist group in order to reinvent themselves after they have been assaulted, or raped. But, it is necessary to pay full attention on two related factors, desire to experience adventure and romance. This situation is especially dangerous to young women from Western Balkan rural area, which offer limited employment opportunities. Due to the growing sense of boredom of youth and discontent with their future outlooks, traveling to the Islamic State offers them a chance for adventure. Also women can be seduced with promises to feel real love with jihadist.

\section{Recruitment of women for terrorist activity}

Studies into terrorism have traditionally focused on men, due to belief that women have assumed passive, inherently less interesting roles in extremist groups. As violent extremism and terrorist radicalization are still often considered a male issue, the question of women terrorist radicalization is characterized by bias and misconceptions. In situations of conflict and violence, women are often seen as passive, victims, helpless, subordinate and maternal. Such assumptions 
reinforce gender stereotypes. As a result, women are neither considered to be potential terrorists, nor perceived to be as dangerous as their male counterparts if they were to be involved in terrorism (OSCE Final Report, 2013:3). Terrorist organization produce a large amount of violent extremist propaganda and recruitment strategies directed at women, so it is fundamental to increase awareness of the existence of and potential for women terrorist radicalization and recruitment strategies directed at women.

Analyzing 54 publications on female terrorism, Jacques and Taylor concluded existence of two forms of recruitment: some of them appear to join terrorist groups voluntarily, whereas others appear to join as a result of recruitment drives by the terrorist group. Principal among these are peer pressure and group conformity, which has been documented as occurring in or through university networks and on-line chat rooms and discussion boards. Women have also been influenced by the men that they are close to and often join terrorist organizations alongside or shortly after their boyfriends, partners, or lovers. Women may also be forced to join extremist groups (Jacques and Taylor, 2009:507).

In Western Balkans we recognize two categories of women that are important for this analysis: Muslim women that began to practice radical Islam and non-Muslim women that converted to radical Islam. Some of this women are radicalized and went to Syria and Iraq, and others are meant to recruit other women. There is no single profile of the typical female recruit, however two distinct groups are evident: young women (as young as 15) who travel to ISIS territory to marry a jihadist and women who are already married and travel with their husband. For young women still living with their parents, evidence from the Western Balkans and elsewhere shows that parents had little to no prior indication that their daughters were being radicalized or had the intention of departing for Islamic State-held territory (Mietz, 2016:5). The ways of radicalization of this women are similar to the ways that are used in rest of Western Europe. In conservative communities, which we can find in some parts of Western Balkans, women can be dictated to by their family members-who they can see, talk to and even marry. For this reason, a large role in the recruitment of women is played by the Internet and by the personal relationships with members of family and female friends that are involved with a terrorist group. Also, Internet plays an immense role when it comes to the recruitment of non-Muslim women and in their conversion to Islam. Through the Internet they can be introduced with the radical Islam, or get in contact with jihadists who will continue their radicalization.

\subsection{Internet Campaigns}

The Internet serves as a critical link between those seeking to participate in terrorism, and those seeking support or recruits for their organizations. It is a growing resource for terrorist organizations to recruit females to extremist activities, because it is used for disseminating terrorist propaganda and instructions to women that might not otherwise have direct contact with group recruiters or supporters. The Internet is accessible, anonymous, low-cost and it offers terrorists a variety of mediums not only to communicate and prepare for operations, but also to disseminate messages and provides connections to women. Not less important, the Internet equally 


\section{Security}

approaches the recruitment of Muslim as it approaches the recruitment of non-Muslim women.

Social networks have vital roles in the recruitment of women in terrorism. Effective social-media campaigns that promise devout jihadist husbands, a home in a true Islamic state and the opportunity to devote their lives to their religion, are the dangerous weapon used for recruitment. Western women inspired by fighters' postings can find women that have beliefs that they have in common among the followers, and build a community. They easily find the Twitter pages and Tumblr accounts of women who have already made it to Syria (muhajirat - female migrants) and feel a sense of intimacy towards these women as if they were close friends. In addition to encouragement, muhajirat provide practical advice to those wishing to travel and, as such, are the key to ensuring that ever more women travel to join "Islamic State". This can include advice on how to overcome the objections and roadblocks raised by family, what clothes to bring, where to attempt a crossing and what to expect on arrival. Although the more general pieces of advice are often contained in blog posts or on public responses on sites such as ask.fm, many of the muhajirat encourage those thinking of travelling to get in touch with them directly through closed messaging apps and direct message (Hoyle et all., 2015:33,34).

Websites provide a more information about terrorist group, their goals, but also may enable education for woman about how they can become more involved in ideological causes and insure support to those already involved in terrorism. These websites can assign to women specific instructions on providing medical care to wounded mujahedeen in twelve specific areas including resuscitation, applying a tourniquet, handling broken bones and treating gunshot wounds (Bakier, 2006). While a large portion of radical online material promotes the role of women as backers of terrorist by supporting and encouraging their husbands, brothers, and male children to take up arms, they are also pressed to indoctrinate their children to radical interpretations of Islam. Furthermore, there are numerous websites that reveal love stories of the women and their loving jihadist, stories of the wonderful life in the Caliphate and many other alluring stories.

\subsection{Personal Relationships}

One of the main reasons that significantly influences the decision of women to join the terrorist organization is the fact that people that are close to these women are already engaged in these organizations. If any family member (father, brother or husband), is already in a terrorist organization, the women are usually harassed to join the organization, or at least to be a sympathizer of one. These women usually come from a highly patriarchal society which expects them to obey men and never question their judgment. This oppressive control makes it very easy for females to be recruited into terrorist organizations since they must follow the decisions made by male family members. (Sutten, 2009:37). Family and social ties plays a significant role in the growth of terrorist organizations: al-Qaeda relied on this method heavily, and "Islamic State" encourage all families to join them promising better life for all.

Numerous cases of women from the West are those who left alone, or with their husbands or partners to join the holy war in Syria. These women usually are very lonely, and in desperate need of a lucid identity. The differences of the Western culture where individuality and independ- 
ence is promoted and praised, does in fact fire back, in the sense that some women feel alienated and therefore are more venerable to manipulation. One of the largest pull factors for some women is the sense of belonging and sisterhood. Search for meaning, sisterhood, and identity is a primary driving factor for many women to travel to Syria (Saltman and Smith, 2015:15). In order to find place where they belong, to sense the feeling of belonging, of unity and community, those women are even ready to become a terrorist. This situation can be completely mapped to the Western Balkans female terrorist.

\subsection{Appeal to Ideology}

A call to action against a perceived injustice has the same draw to women as it does on men. Some claim women are often more interested in causing change since they have the most to gain from sweeping reforms to the political or ideological environment (Sutten, 2009:33). Even in the Islamist terrorist organizations, where the women were initially intended for a secondary role, now it more present than ever the message to all that Jihad is not just a male obligation and responsibility. Women must provide active support and take part in the Holy war. The real need for the involvement of women and the media attention women attract had the influence of making a redefinition of the methods used. Clearly, an appeal to fight for Islam is primarily addressed to Muslim women, but there are responses from non-Muslims who think that Muslims are experiencing injustice and are persecuted.

\section{Roles for Female Terrorists}

Levels of participation by women in terrorism are determined by the goals of the organization as a whole, and the group's opponent. Given that terrorist groups are male dominated, which roles females are allowed to play are decided upon by the men. In many groups, including al-Qaeda and "Islamic State" women were initially blocked from active combat roles, although in others-such as the FARC, the PKK and the Tamil Tigers females were welcomed, and even at times forced, to join as guerilla fighters (Speckhard, 2015:7).

At the beginning, "Islamic State" actively discouraged women from joining. Members active on social media urged their female followers to support Jihad with fundraising and by asking their men folk to join the fight. But as the group came closer to its goal of establishing an Islamic State, exceptions were made. Nowadays, the situation has significantly changed, whereas the women are recruited more often who are looked upon by other women who wish to join them.

The most general classification of women's involvement in terrorism is given by Hearne: direct involvement in terrorist acts; enabling of others to commit such acts; and facilitating the disengagement of others from violent or extremist groups (Hearne, 2009). Hearne concluded that that women are well-placed to both take part in terrorist violence (through direct participation in attacks or in facilitating terrorists), and reduce its impact (by preventing others from participating or by helping those who do join to disengage from violence). This classification is very important and represent start point in researches on women's involvement in terrorism because it recognize the importance of women not only in terrorism, but also in counterterrorist efforts. 


\section{Security}

Sue Mahan and Pamela Griset have conducted an extensive research on gender and terrorism, and have placed the role of women into the four major categories. These categories include sympathizers, spies, warriors, and dominant forces (Sutten, 2009:28). A brief description of each category is included in the Table 1.

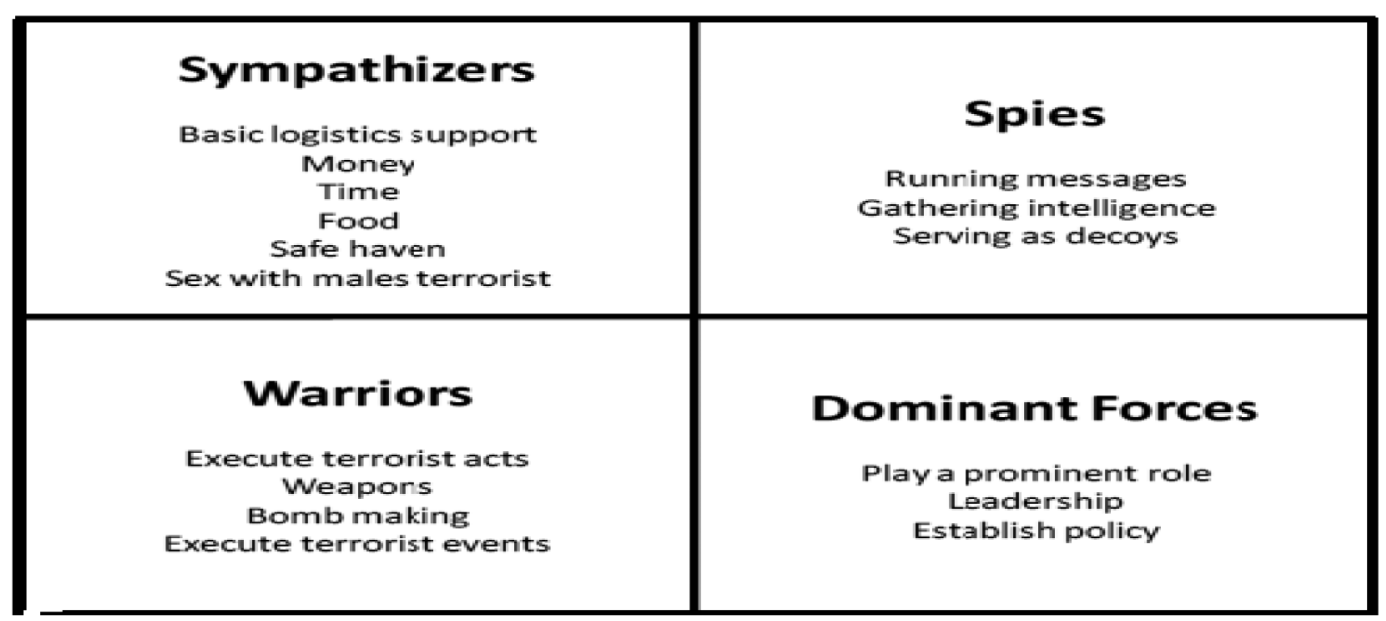

Table 1: Role of women In: Sutten, M. (2009). The Rising Importance of Women in Terrorism and the Need to Reform Counterterrorism Strategy. Fort Leavenworth: School of Advanced Military Studies, pp28.

If we assume that women can play several roles simultaneously, this methodology represents a good attempt of demarcation of different roles women. However, there are some weaknesses, primarily in the fact that it ignores the role of women as a recruiter and her contribution as a jihadist wife. Those roles of women are most common in "Islamic State".

Historically, tasks that women performed in terrorist organizations had varied substantially, often based on political and religious considerations. A the result of this, there is the wide spectrum of roles that women can played in terrorist organization, from women as intelligence gatherers, translators, recruiters, doctors, to suicide bombers and leaders. With evolution of women's involvement in terrorism from secular to Islamic religious settings, some roles become dominant, an others are controversial and challenging, but with much potential for action of great magnitude. So, it is important to examine which are a dominant role in "Islamic Sate" that women can take. That role are also available to the women from this region.

\subsection{Wives of Jihad}

Most women have a role of being a jihadist wife, where her duty is to provide the moral and every other form of support. In this way she indirectly supports the fight. Also, these women will raise their children according to the militant Islamic ideology and also help maintain the "freedom fighter myth" through which insurgents are glorified as heroes. The largest numbers of women 


\section{Security}

coming to Syria and Iraq from Western Balkans have played this exact role. Although they would go through some form of military training, they would not necessarily take an active role in combat. This type of training is done with the aim of training for self-defense.

\subsection{Recruiting daughters for the Caliphate}

One of the crucial role that women have in the terrorist organizations is to recruit new women to terrorist organizations. Recruitment is done primarily through social networks. When it comes to the recruiting of women from the West, it is necessary to get in touch with them, encourage them to change their religion if they are not Muslims, to convince them to go to "Islamic Sate" and connect them with the parties that will enable them logistic support for arrival.

\subsection{Suicide operative}

The advantages of suicide bombings seem clear. They are relatively cheap ways to kill large numbers of people. The would-be suicide either on foot or in a vehicle can move from placeto-place in order to detonate herself/himself where they will cause the most damage. When the operations are successful the sponsoring group does not have to worry about the perpetrators falling into enemy hands. And they have a shock value for the public few other forms of terrorist attack can match. What are the roles for women in these attacks? Women have obvious advantages in carrying out suicide attacks, at least those where the bomber is on foot. They may appear to be pregnant, which has a double benefit. Security personnel are often reluctant to search women who appear pregnant and this permits the would-be suicide bomber to conceal more lethal weapons. And, more generally, women arouse less suspicion than men under identical circumstances. It often permits women to get closer to their targets than their male counterparts. As a result of these benefits, on average, women suicide bombers kill more people per event than their male counterparts. Also, an attack where women commit suicide, a greater media attention is attracted.

\subsection{Controversial roles: leaders and executors}

Throughout the history of modern terrorism, females have been among the leaders roles in many terrorist organization. Women have had leadership roles in the Baader-Meinhof gang (Germany), the Red Brigades (Italy), Front Line (Prima linea) (Italy), the ETA (Basque separatist movement in Spain and France), the Japanese Red Army, the People's Liberation Front for Palestine, the Chechen resistance movement, and the Weather Underground (United States) (Gentry and Sjoberg, 2011:59).

Although the women in "Islamic State" were intended roles separately from combat operations, it is necessary to analyze the possibility that women take more leader-based roles. An example of a member of "al-Khansaa brigade" shows a remarkable degree of cruelty and commitment to the execution of goals.

The ability of women to carry out an execution is another issue that needs attention. Examples where women are committing murder within the frames of "Islamic State" are rare, and 
are usually linked to the situation where woman kill other woman who attempt to escape from this organization. In this way, it is an effective way to intimidate women who may have planned to escape. Women could be murderers, and if a change of their position within the "Islamic State" occurred, the world will be faced with new challenges. Although there is no evidence of the participation of women from Western Balkans in this form of activity, it is necessary to be careful because such circumstances would mean an increased risk to the Western Balkans security on which we don't have an adequate response.

\section{Response of the state and society}

In the analysis of female terrorist from the Western Balkan as a security threat the start point can be establishing the exact number of those who have joined to the "Islamic Sate". At the moment it is impossible to estimate that number, especially because the source that we can consult aren't reliable. For example, Mietz gave estimates number of foreign fighters and migrants from Western Balkan countries, in which he divides number of men and women. But, in below, when he explain the methodology of collecting the data, he wrote "The data represent the ranges currenty found in a variety of media sources, analytical reports and government data"(Mietez, 2016:4). We can find a numerous similar papers in which authors quote figures that are collected by the $\mathrm{NGOs}$, or they analyze media announcements, which gives a lot of place for manipulation of numbers. Also, we don't have reliable information on whether there are women who had regretted that gone to "Islamic Sate", and fled back to Western Balkan countries. These women could play a key role in the deradicalization of other women, because they may convey the true situation from jihadist camps.

Threats to the security of Western Balkan region by women terrorists are real, and they are reflected in at least three ways:

1. existence of women who actively recruit other women;

2. opportunities that the radicalized and trained women from the region, who were in Syria or Iraq, returned to Western Balkan countries and continue their operation, or to become "sleepers"

3. opportunities that women with no previous connection to this area is sent to carry out a terrorist attack.

An answer on how to face with this challenging situation we should try to find in developing an infrastructure for prevention of violent extremist radicalization, and in process of deradicalisation, held by Governments, civil society and NGOs. Prevention work, in its most basic sense, aims to stop processes of radicalisation that lead individuals towards violent extremism. In legal terms for most government's this concern is primarily to do with stopping individuals from becoming terrorists or supporting terrorism (Saltman, Smith, 2015:52). On a regional level, very little attention has been put on preventive measures from the state institutions as well as the civil society.

Beyond the criminal and judicial system, no action has been taken by any of the concerned states to deradicalize or to rehabilitate fighters who return, nor is there sufficient attention being 


\section{Security}

paid to counter violent extremism (CVE) policies and gender. Governments of all countries in the region (with the current exception of Croatia) passed legislation in 2014 or 2015 criminalizing recruitment, participation, incitement, or material support of foreign paramilitary groups by their citizens. Punishments for these criminal offenses generally range from 6 months to 15 years in prison (Mietez, 2016:16). Although the criminalization of this act is good start point, the trend for legal sanctioning only doesn't give solution on the long term. Criminalizing involvement with the "Islamic State" doesn't fully address the migration problem. As Mietez noticed, the solution shows that the government is taking immediate action to punish participants in violent extremism, yet does not address the underlying causes to prevent other individuals from radicalizing and migrating. Second, there is insufficient evidence that police and the courts have the know-how to address women in extremist groups and terrorism in general. Third, prison sentences offer no opportunity for women or men who become disillusioned with the "Islamic State" and who comprehend the seriousness of their actions to reject violent extremism or extremist ideological beliefs altogether. Finally, while the major advantage of criminal legislation serves as a deterrent for potential recruits, the threat of a prison sentence also discourages women who want to escape the Islamic State and return to their home country (Mietez, 2016:14). Also, there are more questions that arises: the specialization of the courts from the region in conducting trials connected with events in Syria, than gathering the evidence and using it afterwards in the courts. For those reasons we can conclude that the implementation of current legislation is challenging on many levels.

More active engagement with local communities in parallel with the criminalization of the foreign fighters could potentially bring better long term outcomes. Engaging communities could be done through direct communication of state authorities and the community or through civil society groups (Bogdanovski, 2014:6). Deradicalisation usually refers to activity aimed at a person who supports terrorism and in some cases has engaged in terrorist related activity, which is intended to effect cognitive and/or behavioural change leading to a new outlook on terrorism and/or disengagement from it (Prevent Strategy, Annex A, 2011). Process of deradicalisation is dominantly administered through government or civil society programs. The objective of these programs: to discourage violent extremist ideologies and to provide participants with opportunities for social inclusion (Saltman, Smith, 2015:58). Promotion of process of deradicalisation with gender perspective, although is challenging, represents priorities on this point. At first, every country should recognize a deradicalisation as important part in struggle against terrorism. Then, it is necessary to produce deradicalisation strategies that are gender sensitive, and implement them through programs. So, it is important to build good infrastructure and capacity within deradicalisation programs handling returnees from Syria and Iraq. Finding an adequate response implies alerting the whole society to this danger and finding partners. In that way he interested parties receive support in order to build civil society capabilities in providing an answer to extremism (Dragišić, Curčić, 2016: 159). Such help may be reflected in support of those organizations leading the campaign against the spread of the Internet material that promotes extremism. There is a great need for developing counter-narratives that are aimed at females. Also, tremendous role can play women-defectors because they can give the real picture of living under the "Islamic State". 


\section{Conclusion}

Terrorism is social phenomenon that is constantly transforming and terrorist are seeking new ways to fulfill their goals. Women are traditionally associated with weakness and non-violence, and therefore exploiting this stereotypes terrorist groups may count on greater shock value on attacks, which strive for to amplify coverage, and, consequently, to terrorize and instil widespread fear. Women's involvement in terrorism is historical constant, but at same time remains a complex phenomenon with no one pathway into involvement and no one catalyst that can explain all women in all movements.

The number of women involved in terrorist activity is growing, including women from Western Balkan, and we can expect that trend will continue in future. And not only has women's involvement grown but it has become more visible in media coverage and scholarly work. Those women aren't just Mothers of next generation of jihadist, but they play multiple roles in terrorist group, and future transformation of terrorism will certainly affect and produce new role for female terrorist. As Western Balkan is a part of Europe, but with its own characteristic, the necessity of researching involvement of women from Western Balkan in terrorist activity is real. In researching of this issue we can consult studies on participation women from Western Europe in terrorism, in order to investigate good and bad experience in this area. After that, we can create a broad profile of females at risk of radicalization based on age, location, ethnicity, family relations or religious background.

Terrorist groups will seek to exploit the advantages of female over male terrorists, so we can expect more frequent terrorist attacks made by women. Those attacks will be accompanied by great media attention, so the ability of the media to be neutral report will become crucial. There will be no place of any glorification of female terrorist by media, otherwise there is possibility that many women find a new role-model and become a member of terrorist organization.

Counterterrorism strategies tend to ignore gender as a relevant factor, and in doing so exclusively focus on male imposed threats. Approaching counterterrorism strategy with a perspective on the female gender as well as the male gender will have a positive impact on the ability of combat terrorism. In establishing mechanism of deradicalization, an emphasis on women is one the best solution and a good basis for counterterrorist strategy. There is a particular lack of infrastructure and understanding around gender dynamics within deradicalisation that would benefit from further development.

\section{Literature}

Bakier, A. (2006) "Jihadis Provide Internet Training for Female Mujahideen" in: Terrorism Focus, Vol 3, Issue 40.

Bloom, M. (2011) "Bombshells: Women and Terror" in: Gender Issues, 28, 1-21.

Bogdanovski, A. (2014) We did criminalize it-now what? Western Balkans response to the foreign fighter's threat. Analytica: Policy brief. 
Dragišić Z. Curčić M. (2016) „Borci iz Srbije u redovima "Islamske države“ kao teroristička pretnja“" in: Politika nacionalne bezbednosti, br.1, 145-162.

Gentry, C. Sjoberg L. (2011) "The Gendering of Women's Terrorism" In: Women, Gender and Terrorism. Athens \& London: The University of Georgia Press pp. 57-80.

Gonzalez-Perez, M. (2008) Women and Terrorism- Female activity in domestic and international terror groups. London, New York: Routledge.

Hearne, E. (2009) "Participants, Enablers, and Preventers: The Roles of Women in Terrorism".

http://is.muni.cz/el/1423/jaro2010/MVZ448/Gender__Terrorism_BISA_Hearne_De c_2009.pdf (visited on 22.04.2017)

Hoyle, C., et.al. (2015) Becoming Mulan? Female Western Migrants to ISIS. London: Institute for Strategic Dialogue.

Jacques, K. Taylor, P. (2009) "Female Terrorism: A Review" in: Terrorism and Political Violence, 21, 499-515.

Mietz, E. (2016) What about the women? Understanding and Addressing the Problem of ISIS Female Recruitment in the Western Balkans. Beograd: BCBP.

Nacos, B. (2008) "The portrayal of female terrorists in the media“ in: Female Terrorism and Militancy: Agency, Utility and Organization. New York: Routledge. pp. 217-235.

OSCE Secretariat-ODIHR Expert Roundtables (2013) Women and Terrorist Radicalization - Final Report. Vienna.

Parliament by the Secretary of State for the Home Department by Command of Her Majesty (2011) Prevent Strategy, Annex A: Glossary of terms.

Persin, A. (2015) "Fatal Attraction: Western Muslimas and ISIS" in: Perspectives on Terrorism, Vol. 9, Issue 3, 21-38.

Saltman, E. Smith, M. (2015) Till Martyrdom Do Us Part - Gender and the ISIS Phenomenon. London: Institute for Strategic Dialogue.

Speckhard, A. (2015) Female Terrorists in ISIS, Al Qaeda and 21rst Century Terrorism. Abu Dhabi: TRENDS Research \& Advisory.

Sutten, M. (2009) the Rising Importance of Women in Terrorism and the Need to Reform Counterterrorism Strategy. Fort Leavenworth: School of Advanced Military Studies.

Zedails, D. (2008) "Beyond the bombings: analyzing female suicide bombers" in: Female Terrorism and Militancy: Agency, Utility and Organization. New York: Routledge. 